IRA-International Journal of Education \& Multidisciplinary Studies ISSN 2455-2526; Vol.04, Issue 03 (2016)

Pg. no. 359-372

Institute of Research Advances

http://research-advances.org/index.php/IJEMS

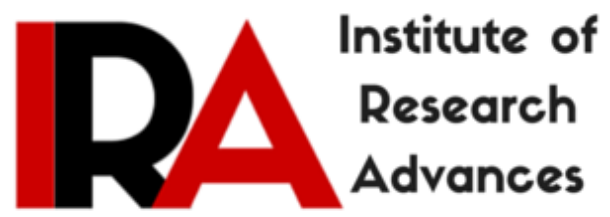

\title{
Home Environment and Academic Self- Concept as Predictors of Career Maturity
}

\author{
Dr. Md. Mahmood Alam \\ Assistant Professor \\ MANUU College of Teacher Education, Sambhal -244302 (U.P.), India. \\ (A Constituent College of Maulana Azad National Urdu University, \\ Hyderabad-India)
}

Type of Review: Peer Reviewed

DOI: http://dx.doi.org/10.21013/jems.v4.n3.p2

\section{How to cite this paper:}

Alam, M. (2016). Home Environment and Academic Self-Concept as Predictors of Career Maturity. IRA International Journal of Education and Multidisciplinary Studies (ISSN 2455-2526), 4(3), 359-372. doi:http://dx.doi.org/10.21013/jems.v4.n3.p2

(C) Institute of Research Advances

\section{(c) EY-NO}

This work is licensed under a Creative Commons Attribution-Non Commercial 4.0 International License subject to proper citation to the publication source of the work.

Disclaimer: The scholarly papers as reviewed and published by the Institute of Research Advances (IRA) are the views and opinions of their respective authors and are not the views or opinions of the IRA. The IRA disclaims of any harm or loss caused due to the published content to any party. 


\begin{abstract}
The present study was conducted to investigate home environment and academic self- concept as predictors of career maturity among adolescents. Descriptive survey method of research was used for collecting the data using Home Environment Scale by Sarla Java and Academic Self Concept Scale (ASCS) by Reynolds et al. (1980). A representative sample of 400 (200 boys and 200 girls) Xth class students was drawn from schools located in the Hyderabad city using simple random sampling technique. Descriptive, correlational and inferential statistics were used to compute correlations and to compare the means between the groups. Findings of the study revealed that (1) there is significant relationship between home environment, academic self-concept and career maturity of students. (2) there is significant difference between boys \& girls and rural \& urban in respect of their home environment, academic selfconcept and career maturity and (3) there is significant difference between rural and urban students in respect of their home environment and career maturity, however insignificant difference is found in case of rural and urban on the measure of academic self-concept. The above analysis suggests that career development of adolescents should be taken as a challenge not only by the adolescents themselves but also by educationists, psychologists and administrators to develop maturity in career decision and goal selection. They should be guided and trained to make congruence between career behaviour and his expected behaviour at that age. Lesser is the gap between the two greater is the maturity in the individuals' career.
\end{abstract}

Keywords: Home Environment, Academic Self- Concept, Career Maturity, Adolescents

\title{
INTRODUCTION
}

"Because the world is making such drastic demands upon the coming workers, every thoughtful man and woman, every teacher and reflecting parent, is planning ways to fit the children for the life and needs of this new century" (Meyer Bloomfield in his book Finding One's Place in Life in 1917 (p. 150).

Adolescence is a time of active vocational development and making career choices are among the most important tasks to be mastered (Creed et al 2007:379). Super's Self-Concept Theory (1957) states that an individual needs to reach a certain state of readiness in terms of self-concept development in order to make an appropriate career choice and this "readiness" is referred to as career maturity. However, as the realities of work change due to such factors as global competition and new technologies, it is necessary to develop new awareness of self in relation to work on one hand and occupational aspirations in the career development of adolescents on the other.Career maturity assumes a great significance in order to make a wise choice towards particular occupation and represents development along a continuum. Greater career maturity and stronger support systems would significantly predict career decision making, self-efficacy and vocational expectations of the individuals (Conkel-Ziebell, 2010). Splaver went on to say "It is important for you to have a good understanding of yourself, your personality, if you are to make intelligent career plans" (Splaver 2000, p. 12).

Although educational and vocational choices are made by an individual but they are certainly influenced by many social and environmental factors which include socio-economic status of the family, home and family environment, sex, age, rural and urban background, psychological factors which may include intelligence, personality, achievement motivation, interest, aptitude, self-concept academic achievement etc. Thus, career selection is not an exclusively intellectual process in which various possibilities are sorted out in a logical manner. Instead, decisions are based on the interaction of career maturity with various social or psychological factors. Studies have also substantiated the beliefs concerning the role of psychosocial variables like intelligence, socio-economic status, parental influence, school influence, needs and values as motivating factors in specific career preferences of adolescents (Vasantha 1977; 
Yadav 1979). The complex interaction of these factors affects individual's readiness to succeed in mastering the tasks appropriate to various stages of career development.

Home environment is the most important institution for the existence and continuance of human life and the development of various personality traits. An ideal home environment is one where there is proper reward to strengthen the desired behavior, provision of opportunities to express its views freely, where the children are not compelled to act according to parental desires and expectations. It has been shown that most of children who are successful and well adjusted come from families where wholesome relationships exist between children and their parents. Daulta (2008) studied the impact of home environment on the scholastic achievement of children and found that good quality of home environment had significant positive correlation with high level of scholastic achievement in boys than among girls. Shek (1997) has found that family factors play an important role in influencing the psychosocial adjustment, particularly the positive mental health, of Chinese adolescents. Whether parents are involved in and support their adolescents' school life can directly affect their personal and social development as well as their academic success (Gecas \& Schwalbe, 1986; Harris \& Goodall, 2008; Jeynes, 2007). Epstein (1992) argues that "students at all grade levels do better academic work and have more positive school attitudes, higher aspirations, and other positive behaviors if they have parents who are aware, knowledgeable, encouraging, and involved". Although schools, peers, and the student's community all have an impact on the young adult's self-identity and career choice, the parent's expectations and perceptions of vocational fit for their children have been found to be the key roles in shaping their career choices (Ferry, 2006). In one study (Creamer \&Laughlin, 2005), this influence has been so strong as to override the influence of teachers, faculty, and career counselors, who likely know more about the career field in question but were not as well-known and/or trusted as the student's parents for this type of decision.

Self is the combination of physical and psychological attributes that is unique to each individual (Shaffer, 2005). The self develop through interactions and acquire information among people around the self to form the social self. This self require social cognition which Shaffer described as the thinking that people display about the thoughts, feelings, motives and behaviours of themselves and others. Shaffer agreed that this will lead the self to self-recognition. The self recognition will help the adolescent to develop physical self concept, psychological self concept and academic self concept, and this in one way or the other, influence the vocational interest of the adolescent and promote the adolescent's self esteem. Self-concept 'is the image or picture the person has of himself, which has developed through childhood and adolescence under the formative influences of home, school and social environment, ...' (Thomas, 1980, p. 24). Super et al. (1963) has suggested that self-concept plays an important role in the formation of career development. With a myriad of different career opportunities available to cater to the different individual personality traits, people tend to compare their self-view with various occupational concepts. In his research, Super claims that self-concept is built through one's physical and mental growth, job observation, adult's career identification and the general experience gathered. The growth of a person's knowledge and experience contributes to the complexity of his or her career self-concept. Super had also suggested that the approach on development and social phenomenological psychology. In his study, Super looked at the four main stages in a person's career development, the first being when the individual is searching for a vocation. This is followed by vocational maturity, which then leads to the transfer of selfconcept to a vocational self-concept and finally, the career pattern itself (Super 1957).

\section{CONCEPTUAL FRAMEWORK}

\section{Career Maturity: Concept and Definition}

Career maturity describes one's ability to successfully cope with vocational development tasks (e.g., crystallizing, specifying, and implementing career choice) that are encountered across the developmental continuum from exploration stage through withdrawal. Simply defined, career maturity provides a means of measuring the degree of affective and cognitive career development an individual has attained. Career 
maturity refers to the individual's degree of readiness to choose, to plan and to prepare for future vocation. According to Super (1963) "career maturity is used to denote the degree of development, the place reached on the continuum of the vocational development from exploration to decline. The career maturity quotient may thus be conceived of as the ratio of vocational maturity to chronological age. It would indicate whether or not the vocational development of an individual is appropriate of this age." Operationally 'career maturity' is defined as the maturity of attitudes and competencies to make appropriate choices, including awareness of what are required to make a career decision and degree to which one choice are both realistic and consistent over time.

\section{Home Environment: Concept and Definition}

Home environment is the quality and quantity of the cognitive, emotional and social support that has been available to the child within the home and connotes the psychological environment of home. The term "home environment" refers to all the objects, forces and conditions (both positive and negative) in the home which influence the child physically, intellectually and emotionally. It is an environment where the child learns the skills, attitudes and behavior which could mould them into a productive and successful student. In accordance with that, a parent's socioeconomic status plays an important role in providing these educational resources and it appears to impose the greatest impact on the child's educational outcomes"( Vellymalay, 2012a). Different home environments vary in many aspects such as the parents' level of education, economic status, occupational status, religious background, attitudes, values, interests, parents' expectation for their children, and family size among others. Operationally home environment refers to aspects of people's domestic lives that contribute to their living conditions.

\section{Academic self-concept: Concept and Definition}

Academic self-concept is the perception and evaluation that a student has or does about his or her academic abilities (Marsh \& Rhonda, 2002). In other words, academic self-concept is how students do school work or feel about themselves as learners (Guay, 2003; Harter, 1998). Academic self-concept studies were pioneered when Shavelson, et al. (1976) developed a multifaceted hierarchical model of selfconcept in which they divided the self-concept into academic and non-academic self concepts (Marsh \& Parker, 1984; Shavelson, et al. 1976).Academic self-concept refers to individuals' knowledge and perceptions about themselves in academic achievement situations (Wigfield \& Karpathian, 1991).Bracken (2009) defines academic self-concept as - how a person feels about himself or herself within a school or academic setting, or in relation to a student's academic progress (p. 92). Academic self-concept is hierarchically organized, and multifaceted in nature (Marsh \& Shavelson, 1985). Math self-concept, verbal self concept, and school self-concept constitute academic self-concept in the current study.

\section{REVIEW OF THE LITERATURE}

The review of literature in research provides the means of getting to the frontiers in a particular field (Borge 1964). This review presents theoretical and empirical justification for the relationship of home environment, academic self-concept and their effect on the career maturity of adolescents. The reviews of literature pertaining to the variable, under investigation are as follows

\section{Home Environment}

J. Patchaivaziamman and S. Krishnamurthy (2011) explored the relative relevance of home environment of B. Ed trainee of Union Territory of Pondicherry. The finding reveals that there is significant difference between male and female in their nature of home environment. Sunitha N.H. and Pushpa Khadi (2005) studied "Academic learning environment of students from aided and unaided coeducational high schools". In result they found no difference between boys and girls in home learning environment. Smith and Forehand (1986) found that females differed significantly from males on 4 of 10 family environment subscales of Moos and Moos. 
Rebecca (2006) in his study posits a significant correlation between career maturity and family environment. Kalra, S. and Gupta, R.(2014) in a study "Career Maturity of Adolescents in Relation to their Home Environment" found(i) No significant difference in career maturity of male and female adolescents; (ii) Significant difference was found in career maturity of adolescents having good and poor home environment. Adolescents having good home environment are more mature about their career as compared to adolescents having poor home environment; and (iii) Significant relationship was found between career maturity and home environment of adolescents. Kaur, S. (2000) found significant relationship between emotional maturity, school, home and psychological environment. Lohita \& Satsangi (2013) conducted a study on "Career Maturity in relation to Family Environment of Senior Secondary Students". They found that family environment is significantly related to career maturity. According to Bradley (1985: 11) home-environment shows generally stronger relation to cognitive development leading to better career maturity.

\section{Academic Self-Concept}

In several studies on gender differences in academic self-concept it has been reported that males and females possess different beliefs about their academic competencies (Ireson, et al. 2001; Wigfield, et al. 2001; Marsh, 1989), with males showing higher academic self-concept than females (Kling, et al. 1999). Different studies have also posited that males tend to have higher academic self-perceptions in science courses while females have higher academic self-perceptions in non-science courses (Harter, 1999; Marsh, 1989).Lau's (1990) study established a significant gender effect, in favour of boys, on adolescents' academic self-concept (Grades 7, 9, 11 and 13).Lau and Leung's (1992) study of Hong Kong adolescents (Grades 7 to 9) likewise substantiated a significant gender effect, in favour of boys, on adolescents' academic self-concept. In a study "Academic Self-Concept: A Cross-Sectional Study of Grade and Gender Differences in a Singapore Secondary School" by Woon, C. L. \& Chee Keng, J. W.(2005) overall academic self-concept is congruent with that obtained by Marsh et al.'s (1985) and Marsh's (1989) Australian studies. They are, however, in contrast to that obtained by Lau's (1990) and Lau and Leung's (1992) study of Hong Kong adolescents. Liu (1994) in his study found that girls' have relatively high overall academic self-concept in comparison to boys. From literature, Wigfield, et al. (2001) and Ireson, et al. (2001) findings concur with the results of this study that there is a difference in the academic self-concept of males and females, that is, males and females possessing different beliefs about their academic competencies. Also, at the same time the results disagree with the findings of a study by Kling, et al. (1999) who highlighted that the males had a higher academic self-concept than females and thus a higher academic achievement for the males compared to the females which is the reverse in this study. However, although various researchers concur with the academic self-concept's correlation with academic achievement, intelligence, self-concept, only a few studies have been done to highlight whether there is a relationship between home environment, academic self-concept and career maturity of school students. On the other hand, the inconsistencies in the findings of the earlier researches compel the present researcher to carry this investigation to ascertain the relationships and differences between the variables in hand.

\section{SIGNIFICANCE OF THE STUDY}

The selection of a career is among the most critical decisions in a person's lifetime. It enables them to review their career decisions in the light of their potentialities. This decision has a far-reaching impact in terms of lifestyle, status, income, security and job satisfaction. In this age of information technology, the choice of a right career/ vocation is becoming difficult and strenuous. The vocational decision at this stage has the counterproductive effect on the future course of action taken by any individual in the world of work. Any inappropriate decision or choice of vocation may act as a hindrance and obstruct the personal growth and development in future. The study of the relationship of career maturity in terms of gender, home environment, academic self- concept will aid educators and guidance counselors to understand more fully the background variables and problems faced by students as they choose their 
careers. This study may challenge educators to continue to create better curriculum and career opportunity programs in order for students to overcome the inequalities brought about by stereotypes. Therefore, it is considered significant to study, "Home Environment and academic Self-Concept as Predictors of Career Maturity among Adolescents”.

\section{OBJECTIVES}

In the light of the review of the literatures, the present investigation was conducted with the following objectives:

1. To find out the relationship between home environment, academic self-concept and career maturity of students.

2. To compare boys and girls (both rural and urban) on the measures of home environment, academic self-concept and career maturity.

\section{HYPOTHESES}

Based on the review of literature and aforementioned objective the present study formulated the following hypotheses:

1. There is no significant relationship between home environment and career maturity of students.

2. There is no significant relationship between academic self- concept and career maturity of students.

3. There is no significant difference between boys and girls on the measure of home environment.

4. There is no significant difference between boys and girls on the measure of academic selfconcept.

5. There is no significant difference between boys and girls on the measure of their career maturity.

6. There is no significant difference between rural and urban on the measure of home environment.

7. There is no significant difference between rural and urban on the measure of academic selfconcept.

8. There is no significant difference between rural and urban on the measure of their career maturity.

\section{METHODOLOGY}

This study utilized survey techniques due to its descriptive nature. This section is comprised of sample, research tool and procedure of the data collection.

\section{Sample}

In the present study the students studying in class Xth of secondary schools located in the Hyderabad city constitute the population. A representative sample of 400 students (200 boys and 200 girls) was drawn using simple random sampling technique from four schools located in the city. Their ages ranged from 14 to 16 years.

\section{TOOLS USED}

The following tools were used for collecting the data to measure the variables of the study.

\section{Home Environment Scale by Sarla Java}

The Home Environment Scale contains 74 items with true and false response alternative. Each item is scored using a five-point likert scale, a graded response can be selected ( $1=$ "rare" to $5=$ "always"). The 
maximum possible score is Three Hundred seventy and minimum is seventy four. High score indicates high level of Home Environment. The reliability for this questionnaire is 0.88 and High validity.

\section{Academic Self Concept Scale (ASCS) by Reynolds et al. (1980)}

The Academic Self Concept Scale is a 40-items Likert- type scale that measures the academic aspect of the general self-concept among college students. Test-retest reliability for the ASCS is reported to be .88 with an internal consistency of 0.91 . The reliability coefficients for the subscales range from 0.59 to 0.92 (Reynolds, 1988). The validity of the scale as established using the administration of the instrument to undergraduate college students was reported to be 0.44 .

\section{Career Maturity Inventory by J.O. Crites adapted by Nirmal Gupta (1989)}

For the present study researcher has used standardized tool viz., Career Maturity Inventory (CMI) (Attitude Scale \& Competency Test), originally prepared by John O' Crites and Indian adaptation by Dr. Nirmal Gupta, 1989. The reliability of the scale was found to be 0.82 by test-retest reliability method. The scale has a high content and constructs validity as expressed by experts in guidance.

\section{PROCEDURE OF DATA COLLECTION}

The administration of the tools viz., Home Environment Scale, Academic Self Concept Scale and Career Maturity Inventory were completed following the instructions given by the respective authors of the tools.The researcher collected the data personally with prior permission of the schools and concerned teachers.

\section{ANALYSIS OF THE DATA}

The researcher used the following statistical techniques for analysis of the data.

I. Descriptive Analysis: Mean and SD

II. Correlational Analysis: Coefficient of Correlation ' $r$ '

III.Differential Analysis: 't'- test

\section{RESULTS AND DISCUSSION}

\section{Correlation of Home Environment, Academic Self Concept Scale and Career Maturity of Students}

The correlation was calculated using Pearson's Product Moment Coefficient of Correlation between these variables. Results of the correlation coefficients between Socio-Economic Status, Home Environment and Emotional Maturity with Career Maturity of the students are presented in Table No. 1

Hypothesis 1: There is no significant relationship between home environment and career maturity of students.

Hypothesis 2: There is no significant relationship between academic self- concept and career maturity of students. 
Table No.1

Correlation Matrix of Home Environment, Academic Self-Concept and Career Maturity

\begin{tabular}{|c|c|c|c|}
\hline Variables & Home Environment & $\begin{array}{c}\text { Academic Self- } \\
\text { Concept }\end{array}$ & Career Maturity \\
\hline Home Environment & 1 & $\begin{array}{c}0.265 \\
(.01)\end{array}$ & 0.319 \\
& & $.01)$ \\
\hline Academic Self-Concept & 0.265 & 1 & .201 \\
& $(.01)$ & & $(.05)$ \\
\hline Career Maturity & 0.319 & .201 & 1 \\
\hline
\end{tabular}

Perusal of table-1 establishes that there is a significant positive correlation between home environment and career maturity. It implies that good home environment results into better career maturity. The reason for the good home environment resulting into better career maturity may be due to parents' positive involvement, getting their children equipped with efficient and effective strategies of acquiring and using knowledge resulting into better study habits and academic performance. Such results is also reported by Russell and Petrie (1992), Gilbert and Rollick (1996), Creemers and Reynold (2000). Thus the hypothesis $\mathrm{H} 1$ is accepted. In case of correlation between academic self concept and academic achievement, the significant positive correlation indicates that academic self concept is directly proportional to academic performance meaning thereby better academic self concept results into proportional academic achievement and vice-versa. The possible reason for this result may be that academic self-concept has a direct positive effect on academic achievement as academic self-concept improves self-perceptions by eliminating self-defeating thoughts and other negative behaviours. This perception may positively affect the confidence and motivate individuals in the learning process. This result is in accordance with the researches of Hattie, (1999), Nonis \& Hudson (2010), Marsh \& Scalas, (2011). Thus the hypothesis H2 is accepted. Concerning the relationship between study habits and academic self concept, the significant positive correlation between them points that self concept in general and academic self concept in particular enables the individuals to hold a realistic view of themselves and their academic abilities. They might perceive and relate their intellectual and academic competence with cognitive interests intelligently which is beneficial for the students in positive academic behaviors and attitudes and ultimately better study habits. Thus the hypothesis $\mathrm{H} 3$ is accepted.

\section{Comparison between gender (boys and girls) on the selected variables.}

The comparison between the samples on the selected variables was done by testing the significance of difference between their means by using t-tests. The results are presented in the following tables.

Hypothesis 3: There is no significant difference between boys and girls on the measure of home environment.

Hypothesis 4: There is no significant difference between boys and girls on the measure of academic self-concept. 
Hypothesis 5: There is no significant difference between boys and girls on the measure of career maturity.

Table No.2

Comparison between Gender (Boys and Girls) on the Selected Variables

\begin{tabular}{|c|c|c|c|c|c|}
\hline \multirow{3}{*}{ Variables } & \multicolumn{4}{|c|}{ Gender } & \multirow{3}{*}{$\mathrm{t}$ - value } \\
\hline & \multicolumn{2}{|c|}{$\begin{array}{l}\text { Boys } \\
(200) \\
\end{array}$} & \multicolumn{2}{|c|}{$\begin{array}{l}\text { Girls } \\
(200) \\
\end{array}$} & \\
\hline & $\mathrm{M}_{1}$ & $\sigma_{1}$ & $\mathrm{M}_{2}$ & $\sigma_{2}$ & \\
\hline $\begin{array}{c}\text { Home } \\
\text { Environment }\end{array}$ & 319.10 & 32.69 & 298.79 & 30.25 & $\begin{array}{l}6.46 \\
(.01)\end{array}$ \\
\hline $\begin{array}{c}\text { Academic } \\
\text { Self-concept }\end{array}$ & 101.32 & 16.85 & 97.73 & 16.16 & $\begin{array}{l}2.17 \\
(.05)\end{array}$ \\
\hline $\begin{array}{c}\text { Career } \\
\text { Maturity }\end{array}$ & 51.19 & 8.96 & 56.26 & 9.17 & $\begin{array}{l}5.59 \\
(.01)\end{array}$ \\
\hline
\end{tabular}

Perusal of the table-2 reveals that mean scores of home environment for boys and girls are 319.10 and 298.79 and their S.Ds are 32.69 and 30.25 respectively. When the t-test was applied to compare the mean scores of both the groups, t-value is found to be 6.46 which is significant at .01 level of significance, suggesting that gender of the students significantly influences their home environment. Hence the null hypothesis 3 is rejected and it may be reframed as there is a significant difference between boys and girls on the measure of home environment. Means and S.Ds of boys and girls on the measure of academic self- concept are $101.32 \& 97.73$ and $16.85 \& 16.16$ respectively. When the t-test was applied to compare the mean scores of both the groups, t-value is found to be 2.17 which is significant at .05 level of significance, suggesting that academic self-concept is significantly influences the gender of the students. Hence the null hypothesis 4 is rejected and it may be reframed as there is a significant difference between boys and girls on the measure of academic self-concept. This significant result favoring boys might be due to high confidence in their ability, emphasis on positive aspects of self and higher preparation to accept their positive evaluation enabling them to increase their activities in desirable direction for facing difficulties with confidence and doing tasks that must be done. This result is in consonance with the research of Kling, et al. (1999) and Brunner, et al. (2009). On the other hand when means and S.Ds of boys and girls on the measure of career maturity were put to t-test, t- value came out to be 5.59 which is significant at .01 level of significance. Hence the null hypothesis 5 is rejected and it may be reframed as there is a significant difference between boys and girls on the measure of career maturity. Thus it may be concluded that girls displaying significant levels of career maturity may be related to them being more psychologically mature than boys (Farmer, 1983).Consequently, girl students may have been more willing to explore future career paths than boys, thus resulting in more career insights and awareness. This finding is consistent with the earlier researches of Rojewski, Wicklein, \& Schell (1995) and Alam (2013). 


\section{Comparison between locality (rural and urban) on the selected variables.}

The comparison between the samples on the selected variables was done by testing the significance of difference between their means by using t-tests. The results are presented in the following tables.

Hypothesis 6: There is no significant difference between rural and urban on the measure of home environment.

Hypothesis 7: There is no significant difference between rural and urban on the measure of academic self-concept.

Hypothesis 8: There is no significant difference between rural and urban on the measure of career maturity.

Table No.3

Comparison between Locality (Rural and Urban) on the Selected Variables

\begin{tabular}{|c|c|c|c|c|c|}
\hline \multirow{3}{*}{ Variables } & \multicolumn{4}{|c|}{ Locality } & \multirow{3}{*}{$\mathrm{t}$ - value } \\
\hline & \multicolumn{2}{|c|}{$\begin{array}{l}\text { Rural } \\
(200)\end{array}$} & \multicolumn{2}{|c|}{$\begin{array}{l}\text { Urban } \\
(200)\end{array}$} & \\
\hline & $\mathrm{M}_{1}$ & $\sigma_{1}$ & $\mathrm{M}_{2}$ & $\sigma_{2}$ & \\
\hline $\begin{array}{c}\text { Home } \\
\text { Environment }\end{array}$ & 301.37 & 29.16 & 315.81 & 30.01 & $\begin{array}{l}4.89 \\
(.01)\end{array}$ \\
\hline $\begin{array}{c}\text { Academic } \\
\text { Self-concept }\end{array}$ & 97.87 & 16.50 & 100.16 & 15.85 & $\begin{array}{l}1.55 \\
\text { (N.S.) }\end{array}$ \\
\hline $\begin{array}{c}\text { Career } \\
\text { Maturity }\end{array}$ & 52.65 & 9.51 & 57.13 & 10.01 & $\begin{array}{l}4.49 \\
(.01)\end{array}$ \\
\hline
\end{tabular}

Perusal of the table-3 reveals that mean scores of home environment for rural and urban are 301.37 and 315.81 and their S.Ds are 29.16 and 30.01 respectively. When the t-test was applied to compare the mean scores of both the groups, t-value is found to be 4.89 which is significant at .01 level of significance, suggesting that locality of the students significantly influences their home environment. Hence the null hypothesis 6 is rejected and it may be reframed as there is a significant difference between rural and urban on the measure of home environment.Means and S.Ds of rural and urban on the measure of academic self- concept are $97.87 \& 100.16$ and $16.50 \& 15.85$ respectively. When the t-test was applied to compare the mean scores of both the groups, $t$-value is found to be 1.55 which is non significant, suggesting that academic self-concept is not influenced by locality (rural and urban) of the students in this case. Hence the null hypothesis 7 is accepted. Non-significant result between rural and urban students on 
the measure of academic self concept might be due to the fact that rural students are equally receptive to and benefit from family help to keep them aspired and motivated and utilize their talents by visualizing distal goals. This perception might affect the confidence level in the learning process which, in turn, helps them equally in academic self concept formation. In a study by Devi \& Prasanthi ((2004), no significant difference between rural and urban on the measure of academic self concept is reported. On the other hand when means and S.Ds of rural and urban on the measure of career maturity were put to t-test, $\mathrm{t}$ value came out to be 4.49 which is significant at .01 level of significance. Hence the null hypothesis 8 is rejected and it may be reframed as there is a significant difference between rural and urban on the measure of career maturity. Significant result favoring urban students on the measure of career maturity indicates that urban students may have a relatively more secure socio-psychological environment and economic vitality for the educational, vocational and career alternatives, which may help them to set realistic goals for themselves that will help fulfill their future expectations. They may have the greater chance to share their experiences with fellow urban students who may have similar experiences as they were defining their career path and thus develop their career maturity. This finding gets the support from the finding of Rojewski, (1994).

\section{CONCLUSION}

It can be concluded from this study that demographic characteristics have significant correlation with career maturity of school students. The study also showed a statistically significant difference between the home environment, academic self-concept and career maturity of boys \& girls and rural \& urban students. However, the study did not reveal any statistically significant difference between the academic selfconcept of rural and urban students in Hyderabad City high schools. This finding suggest that when both boys $\&$ girls and rural $\&$ urban students are given opportunities and support in school, both sexes of rural and urban will develop their abilities and competences and will thus strive to work hard to achieve their career goals. Vocational guidance and counseling needs to be introduced as an integrated component of the curriculum at all stages of school curriculum with diverse objectives depending upon the needs of the students in each stage of education. This would ensure a strong foundation to make career decisions appropriately at secondary and senior secondary stages of education. Moreover, during the secondary stage well formulated and realistic concepts about self and the world of work need to be developed which would make for easier transition from school to work.

\section{REFERENCES}

1. Alam, M.M. (2013), "Study of gender difference in career maturity of rural and urban students in India”, Global Journal of Scientific Researches, Vol. 1, No. 1, pp. 19-25.

2. Bracken, B. A. (2009), “ Positive self-concepts,” In R. Gilman, E. S. Huebner, \& M. J. Furlong (Eds.), Handbook of positive psychology in the schools, New York, NY: Routledge, pp. 89-106.

3. Brunner, M., Keller, U., Dierendonck, C., Reichert, M., Ugen, S., Fischbach, A., and R. Martin (2010), "The structure of academic self-concepts revisited," The nested Marsh/Shavelson model. Journal of Educational Psychology, Vol. 102, pp. 964-981. doi:10.1037/a0019644

4. Conkel-Ziebell, J.L. (2010), “ Promoting viable career choice goals through career-decision making self-efficacy and career maturity in inner-city high school students: A test of social cognitive career theory," Unpublished Ph.D. Thesis, University of Minnesota, Dissertation Abstracts International, Vol.71, No. 10. Retrieved from http:xmas.dvdesign.com/cgibin/amazon.cgi?operation=item.

5. Creamer, E.G. and Laughlin, A. (2005), "Self-authorship and women's career decision making," Journal of College Student Development, Vol.46, No. 1, pp.13-27. 
6. Creed, P.A., Patton, W. and L. Prideaux, L. (20070, "Predicting change over time in career planning and career exploration for high school students," Journal of adolescence, Vol.30, pp.377-392.

7. Creemers, B. and Reynold, D. (2000), "School effectiveness and school improvement," International Journal of Research, Policy and Practice, Vol. 22, pp. 4-11.

8. Daulta, M. S. (2008), "Impact of home environment on the scholastic achievement of children," Journal of Human Ecological, Vol. 23, No.1, pp.75-77. Retrieved from www.krepublishers.com/JHE-23-1-075- 08-1497-Siwach-M-Tt.pdfý

9. Devi, T.K. and Prasanti, S. (2004), "Self concept of adolescents in urban and rural areas", Indian Psychological Rev., Vol. 62, pp. 202-206.

10. Epstein, J. (1992), "School and Family Partnerships," In M. Alkin (Ed.), ENCYCLOPEDIA OF EDUCATIONAL RESEARCH, Sixth Edition. New York: MacMillan.

11. Ferry, N.M. (2006), "Factors influencing career choices of adolescents and young adults in rural Pennsylvania," Journal of Extension, Vol. 44, No. 3, pp. 1-6.

12. Gecas, V. and Schwalbe, M. L. (1986), "Parental behavior and adolescent self-esteem," Journal of Marriage and Family, Vol. 48, pp.37-46.

13. Gilbert, J. N. and Rollick, T. (1996), "Evaluation of a life skill program with children," Journal of Elementary School Guidance and Counseling, Vol. 31, pp.139-152.

14. Guay, F. (2003), "Academic self-concept and achievement: Developmental perspective on their causal ordering," Journal of Educational Psychology, Vol. 95, pp.124-136.

15. Gupta, N. (1989), "Manual for Indian Adaptation of Career Maturity Inventory (CMI)," Agra: National Psychological Corporation.

16. Harris, A. and Goodall, J. (2008), "Do parents know they matter? Engaging all parents in learning," Educational Research, Vol. 50, pp. 277-289.

17. Harter, S. (1998), "The development of self-representations," In Damon, W., \& Eisenberg, N. (ed.), Handbook of child psychology, Vol. 3, No. 5, pp. 553-617. New York: John Wiley and Sons.

18. Harter, S. (1999), "The construction of the Self: A developmental perspective," New York: Guilford Press.

19. Hattie, J. A. (1999), "Influences on student learning," Inaugural professorial address, University of Auckland, New Zealand). Retrieved from http://www.arts .auckland.ac.nz/staff/index.cfm?P=8650

20. Ireson, J. and Hallam, S. (2001), “Ability grouping in education,” London: Chapman.

21. Jeynes, W. H. (2007), "The relationship between parental involvement and urban secondary school student academic achievement: A meta-analysis," Urban Education, Vol. 42, pp. 82-110.

22. Kling, K. C., Hyde, J. S., Showers, C. J. and B. N. Buswell (1999), "Gender differences in selfesteem: A meta-analysis," Psychological Bulletin, Vol. 125, pp. 470-500.

23. Lau, S. (1990), "Crisis and vulnerability in adolescent development," Journal of Youth and Adolescence, Vol. 19, No. 2, pp. 111-131. 
24. Lau, S. and Leung, K. (1992), "Relations with parents and school and Chinese adolescents' selfconcept, delinquency, and academic performance," British Journal of Educational Psychology, Vol. 62, pp. 193-202.

25. Liu, W. C. (1994), "Academic self-concept in a streamed setting: Home environment and classroom climate factors," Unpublished M.Ed. dissertation, University of Nottingham, England.

26. Marsh, H. W. (1989), "Age and sex effects in multiple dimensions of self-concept: Preadolescence to early adulthood," Journal of Educational Psychology, Vol. 81, No. 3, pp. 417430.

27. Marsh, H., and Rhonda, G. (2002), "The pivotal role of frames of reference in academic selfconcept," In Pajares, F. \& Urdan, T. (coord.). Academic motivation of adolescents. Inglaterra: Information Age Publishing, Mars.

28. Marsh, H. W. and Parker, J. W. (1984), "Determinants of student self-concept: Is it better to be a relatively large fish in a small pond even if you don't learn to swim as well?," Journal of Personality and Social Psychology, Vol. 47, pp. 213-231.

29. Marsh, H. W., Parker, J., \& Barnes, J. (1985), "Multidimensional adolescent self-concepts: Their relationship to age, sex and academic measures," American Educational Research Journal, Vol. 22, No. 3, pp. 422-444.

30. Marsh, H. W. and Scalas, L. F. (2011), "Self-concept in learning: Reciprocal effects model between academic self-concept and academic achievement," In S. Järvelä (Ed.), Social and emotional aspects of learning, Oxford, England: Academic Press, pp. 191-198.

31. Marsh, H. W., and Shavelson, R. J. (1985), "Self-concept: Its multifaceted, hierarchical structure," Educational Psychologist, Vol. 20, pp.107-125.

32. Musa, M. (2012), "Academic Self-Concept and Academic Achievement among University Students" International Online Journal of Educational Sciences, Vol. 4, No. 1, pp.107-116.

33. Nonis, S. A. and Hudson, G. I. (2010), "Performance of college students: Impact of study time and study habits," Journal of Education for Business, Vol.85, No. 4, pp. 229-238.

34. Rojewski, J. W. (1994), "Career indecision types for rural adolescents from disadvantaged and non-disadvantaged backgrounds," Journal of Counseling Psychology, Vol. 41, pp.356- 363.

35. Rojewski, J. W., Wicklein, R. C. and J. W. Schell, (1995), "Effects of gender and academic risk behavior on the career maturity of rural youth," Journal of Research in Rural Education, Vol. 11, No. 2, pp. 1-12.

36. Russell, R. K. and Petrie, T. A. (1992), "Academic adjustment of college students: Assessment and counseling," In S. D. Brown, R. Lent (Eds.), Handbook of counseling psychology (2nd ed.), Oxford England: John Wiley \& Sons, pp. 485-511.

37. Shavelson, R. J., Hubner, J. J. and G. C. Stanton (1976), "Self-concept: Validation of construct interpretations," Review of Educational Research, Vol. 46, pp. 407-441.

38. Shek D.T.L. (1997), "Family environment and adolescent psychological well-being, school adjustment, and problem behavior: A pioneer study in a Chinese context," Journal of Genetic Psychology, Vol.158, No. 4, pp.467- 479.

39. Shafter, D.R. (2007), "Social and Personality Development," 5th Edition. Wadsworth U.S.A.

40. Super, D. E. (1957), “The Psychology of Careers,” New York: Harper \& Row. 
41. Super, D. E., Starishevsky, R. and N. Matlin (1963), "Career Development: A Self-Concept Theory," New York: College Entrance Examination Board.

42. Thomas, J. B. (1980), “The self in education,” Windsor: NFER Publishing Company Limited.

43. Vasantha, A. (1977), "A socio-economic study of work values," Journal of Psychological Researches, Vol. 21, No. 2, pp. 119-121.

44. Vellymalay, S. (2012a), "Parental Involvement at Home: Analyzing the Influence of Parents' Socioeconomic Status," Studies in Sociology of Science, Vol. 3, No. 1, pp. 1-6. DOI:10.3968/j.sss.1923018420120301.2048

45. Wigfield, A., Battle, A., Keller, L. B. and J. S. Eccles (2001), "Sex differences in motivation, self-concept, career aspiration and career choice: implications for cognitive development," In A. Mc Gillicuddy-De Lisi, \& R. De Lisi (eds.). Biology, society, and behaviour: the development of sex differences in cognition. Westport, CT: Greenwood.

46. Wigfield, A., and Karpathian, M. (1991), "Who am I and what can I do? Children's self-concepts and motivation in achievement situations. Educational Psychologist, Vol. 26, pp.233-261.

47. Woon Chia Liu Chee Keng John Wang (2005), "Academic Self-Concept: A Cross-Sectional Study of Grade and Gender Differences in a Singapore Secondary School", Asia Pacific Education Review, Vol. 6, No. 1, pp.20-27.

48. Yadav, R. K. (1979), "A study of motives for the vocational preferences of adolescents," Indian Educational Review, Vol. 29, No.2, pp.78-79. 